\title{
CROSS-COUNTRY ANALYSIS OF THE EFFECTIVENESS OF HEALTH SYSTEMS
}

\author{
Elena M. Razymovskaya ${ }^{1}$ \\ Gulnara F. Valeeva ${ }^{2}$
}

\begin{abstract}
Assessing the effectiveness of health systems is a relevant issue due to the recognition of health as the main human value, as well as the evidence of the impact of public health indicators on the socio-economic development of a state or region. Annually, analysts compile inter-country health ratings. The Most Efficient Health Care (Bloomberg financial and economic information agency), the countries ranking according to the level of medicine by the Health Care Index for Country (Numbeo) and the Euro Health Consumer Index (Health Consumer Powerhouse) are among the most respected countries in the world. Bloomberg Agency also compiles a rating of the healthiest countries (Global Health Index): in our opinion, this rating is the result of all ratings of health system performance, because the main goal of any country in the field of health is to
\end{abstract}

maintain public health. According to The Most Efficient Health Care rating in 2018, Hong Kong, Singapore, Spain, Italy, and South Korea were in the top 5. Russia ranked 53rd of 56 in this ranking. Taiwan, South Korea, and Japan are the leaders in the latest published Health Care Index for Country ranking. Russia is on the 60 th place out of 84 . The leaders in 2019 according to the ranking of the healthiest countries (Global Health Index) are Spain, Italy, Iceland, Japan; Russia ranks 95th (of 169 countries). According to the Euro Health Consumer Index (EHCI), the leaders of 2018 are Switzerland, the Netherlands, Norway, Denmark (the rating does not include Russia). The methodology of each of the health system performance ratings is different, however, each rating is a guideline and subject of analysis for countries in order to adjust the

\footnotetext{
${ }^{1}$ Kazan Federal University Institute of Management, Economics and Finance. e-mail: gfvaleeva@gmail.com. Tel.:+79655894890.

${ }^{2}$ Kazan Federal University Institute of Management, Economics and Finance. e-mail: gfvaleeva@gmail.com. Tel.:+79655894890
} 
implementation of state health policy. For this reason, the study and analysis of rating calculation methods and the assessment of the dynamics of countries' positions in them is an urgent task of modern scientific research, which as a result should contribute to improving the efficiency of the health system in individual countries.

Keywords: healthcare, healthcare system efficiency, intercountry ratings, Bloomberg, Numbeo, life expectancy.

\section{Introduction}

Health care is the activity to ensure, maintain, and enhance the health of all categories of citizens, carried out by state, regional and local authorities, specialized organizations, their leaders and citizens [1].

Health care is one of the key factors in the formation of the socioeconomic potential of the region, and therefore, improving the quality of life of its population. Health is a basic factor in the development of human capital, strengthening the competitiveness and national security of the region and the country as a whole [2].

There are three types of effectiveness in health care: medical, social, and economic. Medical effectiveness is the resultant indicators of the health status of the population, diagnostics of the treatment of various pathologies and preventive measures. Social performance reflects how the population is satisfied with the quality and accessibility of their medical care. Economic efficiency is an assessment of the impact that indicators of public health have on macroeconomic indicators (GRP, economic growth, national income, social development, etc.) [3].

The objective of this study is to study the calculation methods for the four intercountry ratings for assessing healthcare (the effectiveness of healthcare systems and the level of population health) and to analyze the positions of countries (including Russia) in each of them.

\section{$2 \quad$ Methods}

The methodological base of the study is represented by a comparative method, which includes a qualitative and quantitative comparison of the considered ratings of the effectiveness of health systems. 


\section{Results and discussion}

Bloomberg's The Most

Efficient Health Care rating is based on data from WHO, the United Nations, and the World Bank and on three indicators:

1) average life expectancy at birth;

2) public spending on health $(\%$ of GDP per capita);

3 ) the cost of medical services in terms of per capita [4].

The ranking includes countries with a population of more than 5 million people, GDP per capita is over $\$ 5,000$, and life expectancy exceeds 70 years: all this already speaks of a good healthcare system in these countries. In 2018, there were only 56 such countries - this is $23 \%$ of all countries in the world.
According to the results of the rating, the country with the highest life expectancy and the lowest health financing is the highest score. That is, efficiency means the ability to achieve better results for less - focusing on this principle, the effectiveness of regional health systems is calculated in Russia [5].

Calculation of the rating neglects many factors such as corruption, the salaries of doctors, etc. but, nevertheless, it is objective, recognized in the world and clearly shows the price / quality ratio of medical services.

Let us analyze the indicators of the leaders of the 2018 rating [4]:

Table 1: The leaders of The Most Efficient Health Care rating, 2018

\begin{tabular}{|l|l|c|l|c|c|}
\hline No. & Country & Efficiency & $\begin{array}{l}\text { Life } \\
\text { Relative }\end{array}$ & $\begin{array}{l}\text { Relative Cost } \\
(\%)\end{array}$ & $\begin{array}{l}\text { Absolute Cost } \\
(\$)\end{array}$ \\
\hline 1 & $\begin{array}{l}\text { Hong } \\
\text { Kong }\end{array}$ & 87,3 & 84.3 & 5.7 & 2,222 \\
\hline 2 & Singapore & 85.6 & 82.1 & 4.3 & 2,280 \\
\hline 3 & Spain & 69.3 & 82.8 & 9.2 & 2,354 \\
\hline 4 & Italy & 67.6 & 82.5 & 9.0 & 2,700 \\
\hline
\end{tabular}




\begin{tabular}{|c|c|c|c|c|c|}
\hline No. & Country & Efficiency & $\begin{array}{l}\text { Life Span } \\
\text { Relative }\end{array}$ & $\begin{array}{l}\text { Relative Cost } \\
(\%)\end{array}$ & $\begin{array}{l}\text { Absolute Cost } \\
(\$)\end{array}$ \\
\hline 5 & $\begin{array}{l}\text { South } \\
\text { Korea }\end{array}$ & 67.4 & 82.0 & 7.4 & 2,013 \\
\hline
\end{tabular}

In Spain, which ranked third in the final ranking, life expectancy is 83 years, the share of health spending is $9.03 \%$ of GDP. Close attention is paid to training specialists and affordable medicine. The Spanish doctor has been studying for 10 years, passes the world's most difficult MIR medicine exam and undergoes extensive practice. Spain is one of the three countries with the lowest death rates from cardiovascular diseases in the world.

In Singapore, life expectancy is 82 years, the share of health care expenditures is $4.92 \%$ of GDP, and medicine is high-tech. Here, citizens must transfer $10 \%$ of their salary to a personal special account, used to pay then for medical services. The state subsidizes up to $80 \%$ of medical services to poor citizens.

The leader is Hong Kong, where life expectancy is 84 years, the cost of medical services per capita is estimated at $\$ 2,022$, the share of health care costs is also high $-5.7 \%$ of GDP. Health care costs are tightly controlled by the state. Officials are responsible for the health of citizens. For example, after the spread of the SARS virus, the head of the Hong Kong administration was forced to resign. The state pays up to $90 \%$ of the cost of medical services for each citizen.

We shall consider the rating of 2016. The leaders of this rating were the same countries that are leading today with the following ratings: Hong Kong 88.9, Singapore - 84.2, Spain - 72.2.

In 2013, Singapore was also the leader of the rating but in 2014 it briefly gave the first place to Hong Kong. The third place in 2013 was occupied by Japan, which ranked 5th in 2016, and only 7 th in 2018 . In 2014, Italy moved up to third place, for comparison - in 2016 it was sixth, and in 2018 - fourth. Quantitative data shall be represented as follows: 
Table 2:The leaders of The Most Efficient Health Care rating, 2013-2014

\begin{tabular}{|r|r|r|r|r|r|r|}
\hline 2014 & \multicolumn{2}{|l|}{2013} & Assessment & \multicolumn{1}{l}{ No.1 } & \multicolumn{1}{l}{ No.2 } & \multicolumn{1}{l}{ No.3 } \\
\hline 1 & 2 & Singapore & 78.6 & 82.1 & 4.5. & 2,426 \\
\hline 2 & 1 & Hong Kong & 77.5 & 83.5 & 5.3 & 1,944 \\
\hline 3 & 6 & Italy & 76.3 & 82.9 & 9.0 & 3,032 \\
\hline 4 & 3 & Japan & 68.1 & 83.1 & 10.2. & 4,752 \\
\hline
\end{tabular}

As for the outsider countries, in 2013 it was Brazil, Serbia, the USA, in 2014 - Azerbaijan, Brazil, Russia (while Russia in 2013 was not included in this rating, and the USA slightly improved its performance). In 2016, the same countries as in 2014 became outsiders: Azerbaijan, Brazil, Russia (the United
States was not represented in the 2013 ranking).

As a result of the 2018 rating, the last were Russia, Azerbaijan, the USA, and Bulgaria, which worsened its performance compared to previous years. Here are the data of the 2018 rating:

Table 3: The outsiders of The Most Efficient Health Care rating, 2018

\begin{tabular}{|r|r|c|c|c|c|}
\hline No. & Country & Efficiency & $\begin{array}{r}\text { Life Span } \\
\text { Relative }\end{array}$ & $\begin{array}{l}\text { Relative Cost } \\
(\%)\end{array}$ & $\begin{array}{l}\text { Absolute } \\
\text { Cost }(\$)\end{array}$ \\
\hline 53 & Russia & 31.3 & $71, .2$ & 5.6 & 524 \\
\hline 54 & Azerbaijan & 29.6 & 71.9 & 6.7 & 968 \\
\hline 55 & USA & 29.6 & 78.7 & 16.8 & 936 \\
\hline
\end{tabular}




\begin{tabular}{|r|r|l|l|l|r|}
\hline 56 & Bulgaria & 29.4 & 74.6 & 8.2 & 572 \\
\hline
\end{tabular}

We shall consider the rating of countries in terms of the Health care index for country, which is compiled by the largest database of cities and countries in the world - Numbeo.

In this rating, experts evaluate the overall quality of healthcare systems, equipping hospitals with necessary equipment, the professionalism of medical personnel, and the cost of services in medical institutions. The key point here is the fact that information is collected on the basis of a survey of the population of large cities of the respective countries. Questions are answered in the range of grades +2 and 2. The rating takes into account the following factors:

- $\quad$ skills and competencies of medical personnel;

$$
\text { - speed of filling out }
$$

reports (paper documentation);

- the availability of equipment for diagnosis and treatment;

- accuracy and

completeness of filling out reports;

- $\quad$ friendliness and courtesy of staff;

- $\quad$ satisfaction with waiting times in medical institutions;

- $\quad$ satisfaction with the cost

of medical services;

- convenience of the location of the medical facility.

The survey data is calculated on a 100-point scale, that is, the country with the highest rating has a coefficient of 100 and the lowest - 0 . Let us present the results of calculating the 2019 rating [6]:

Table 4:Health care index for country rating, 2019

\begin{tabular}{|r|r|c|}
\hline No. & & Index \\
\hline 1 & Country & 86.2 \\
\hline 2 & Taiwan & 84.51 \\
\hline
\end{tabular}




\begin{tabular}{|c|c|c|}
\hline No. & & Index \\
\hline 3 & South Korea & 80.40 \\
\hline 82 & Venezuela & 41.24 \\
\hline 83 & Bangladesh & 40.33 \\
\hline 84 & Morocco & 36.87 \\
\hline
\end{tabular}

We shall compare the positions of leaders and outsiders of The Most Efficient Health Care rating with this rating. Hong Kong took only 37 th place, gaining 67.35 points, Singapore - 27th place with 70.30 points, and Spain - 10th place with 77.77 .

Bulgaria took 70th place with 54.04 points, Azerbaijan was not represented in the rating, the United States took 29th place with 69.41 points, Russia - 60th place with 57.63.

All this indicates the inconsistency of the data of the two ratings, which is explained by the fact that The Most efficient health care rating is compiled on the basis of statistics, and the Health care index for country is based on a survey.

The key results in assessing the effectiveness of the healthcare system are changes in the state of public health [7]. In this regard, we consider the Bloomberg's ranking of the healthiest countries (Global Health Index). The rating includes 169 countries and is based on official data from WHO, the United Nations Population Division, and the World Bank - factors that affect the overall health of these countries are evaluated. This takes into account indicators such as life expectancy, measures to combat smoking, alcoholism, obesity and high blood pressure, environmental indicators, access to clean water and medicine, etc.

The leaders of the 2019 rating are Spain (the highest life expectancy at birth among the countries of the European Union, and it is second only to Japan and Switzerland in the world), Italy, Iceland, Japan, Switzerland, 
Sweden, Australia, Singapore, Norway and Israel. Of the closing list of 30 countries, 27 are located in sub-Saharan Africa, the remaining three are Haiti, Afghanistan and Yemen.

The next rating of global healthcare systems is the Euro Health Consumer Index (EHCI). This rating ranks health systems on the basis of 46 indicators, mainly indicators of patient rights, prevention of their health, patient access to information (including in electronic form), as well as electronic document management in the health system as a whole. It is compiled annually by the Health Consumer Powerhouse based on an analysis of 35 countries. The leaders of the 2018 rating were Switzerland, the Netherlands, Norway, Denmark, Belgium, Finland, Luxembourg, Sweden, Austria, and Iceland. Outsiders were Poland, Hungary, Romania, and Albania [8].

We shall consider the position of the Russian Federation in the above ratings.

Russia entered The Most Efficient Health Care rating for the first time in 2014. This is because until that time, the average life expectancy of the Russian population was less than 69
8

years. Based on the ratings of 2014 and 2016. she took the last place in the rating: 51th place with a score of 22.5 points in 2014, and the last 55th place with a score of 24.3 points in 2016th. In the ranking of 2018, Russia with 31.3 points took only 53 place - with indicators of average life expectancy of the population of 71.2 years, the cost of medical services per capita of \$524 US, the share of government spending on health care $5.6 \%$ of GDP. This indicates that Russia in terms of financing the health sector is clearly lagging behind East Asian and West European countries [9].

the 60th place of 84 in the Numbeo rating, no doubt, does not characterize Russia as a country with affordable and high-quality medicine.

In the rating of the healthiest countries in the world, the Global Health Index-2019, Russia took 95th place, which reflects the low level of population health.

\section{Summary}

Of course, Russia's current indicators in these ratings characterize it as a country with an ineffective health care system, which indicates the need to adjust public health policy. The 
adjustment should be aimed at taking into account the differentiation of regions according to socio-economic development, increasing financing of the state healthcare system to at least $5 \%$ of GDP, increasing the level of healthcare organizations and organizers, increasing the share of the population leading a healthy lifestyle, and improving preventive health promotion measures.

The result of this policy should be the improvement of health indicators, the main of which is an increase in life expectancy - all this should have a positive effect on Russia's position in intercountry ratings.

\section{Conclusion}

The need for cross-country ratings of the effectiveness of health systems and the level of health of the population is out of doubts: the difference in the methods of their assessment should facilitate a comprehensive review by countries of this crucial aspect of state development. The calculation of ratings based on quantitative and polling methods also stimulates public authorities to take a diversified approach to achieving the main goals in the field of health - strengthening public health and increasing life expectancy. However, we should note the impossibility of creating any unified approach to building an effective health care system: it is more related to the existing medical care system and the socio-economic conditions for the implementation of public health policy than to the implementation of specific management methods [10] . In other words, countries, when adjusting their health policy, must take into account the particular functioning of the national health system, using all its advantages and opportunities, taking into account existing negative trends and eliminating existing threats.

Russia, which lags behind in all the ratings considered in the study, needs to adjust the current public health policy, which is the object of further research.

\section{Acknowledgments}

The work is performed according to the Russian Government Program of Competitive Growth of Kazan Federal University.

\section{References}

Valeeva G.F. Public health management in the Russian Federation // Russian Studies in Law and 
Politics. - Volume 2. - Number 2. - 2018. - p.48.

Borovkova G.A., Valeeva G.F. Health care as a factor in the formation of the socio-economic potential of the region // Problems and prospects for the development of the socio-economic potential of the Russian regions: materials of the 7th All-Russian Scientific and Practical Conference. Cheboksary, December 13-14, 2018.

Cheboksary: Publishing house of the Chuvash University, LLC "Publishing House "Pegas". - 2018. — p.13.-18.

Medeiros J., Schwierz C. Efficiency estimates of health care systems // European Economy. Economic Papers.— № 549.— 2015.

Official site Bloomberg.- URL: www.bloomberg.com/europe

Ulumbekova G.E., Ginoian A.B., Kalashnikova A.V. The effectiveness of regional health care systems in Russia // Bulletin of the Higher School of Education. - 2017 - No. 3. - URL: https://www.vshouz.ru/journal/2017/eff ektivnost-regionalnykh-sistemzdravookhraneniya-rossii/x
10

Official site Numbeo.- URL:

https://www.numbeo.com/cost-of-

living/

Donabedian A. The role of outcomes in quality assessment and assurance // Quality Review Bulletin._-1992._№18.-Pp. 356-360.

Euro Health Consumer Index 2018 Report

URL:

https://healthpowerhouse.com/media/E

$\underline{\text { HCI-2018/EHCI-2018-report.pdf }}$

Iashina N.G., Grishunina I.A., Iashin K.S. Methodology for assessing the effectiveness of budgetary resources management in the healthcare sector // Economic analysis: theory and practice.- 2015. - №21. - URL: https://cyberleninka.ru/article/n/metodik a-otsenki-effektivnosti-upravleniya-

byudzhetnymi-resursami-V-sferezdravoohraneniya

Shibalkov I.P. Evaluation of the effectiveness of the organization of the healthcare system: foreign experience // Siberian Science Bulletin. - 2016.No. $1 .-\quad$ URL: https://cyberleninka.ru/article/n/otsenka -effektivnosti-organizatsii-sistemyzdravoohraneniya-zarubezhnyy-opyt 